\title{
The Meaning Construction of Public Relations Marketing of Islamic Private Higher Education PR
}

\section{Konstruksi Makna Marketing Public Relations bagi Humas Perguruan Tinggi Swasta Islam}

\author{
Tresna Wiwitan ${ }^{1}$, Neni Yulianita ${ }^{1}$ \\ ${ }^{1}$ Faculty of Communication Sciences, Universitas Islam Bandung, Jl. Tamansari No. 1, \\ Bandung 40116, Indonesia \\ *Corresponding author, e-mail: tresna@unisba.ac.id
}

\begin{abstract}
The reality that occurs today is that Private Universities is still unable to compete with State Universities. Unisba and Unissula are Islamic Private Universities working hard to gain public trust through improving the academic quality of the lecturers and the students. Research issue that will be studied is the dimension of the meaning construction of PR Marketing in Unisba and Unissula. This research is qualitative research with case study approach. The theory used to examine and to analyze the results of the research is the Theory of Social Construction (Berger and Luckman). The results of research stated that the meaning construction of PR Marketing are: 1) the art of persuading the stakeholders in the framework of human relations, 2) the intention of worshipping because of Allah SWT (Lillahi Ta'ala) based on patience, honesty, and exemplary, 3) the motive to increase the number of prospective students and to build positive image, and 4) PR Marketing puts forward the values of Islam that contains the values of Islamic da'wah and syi'ar.
\end{abstract}

Keywords: Marketing Public Relations, Social Construction, Islamic Shari'a.

\begin{abstract}
Abstrak
Realitas yang terjadi saat ini Perguruan Tinggi Swasta (PTS) masih kalah bersaing dengan Perguruan Tinggi Negeri (PTN). Unisba dan Unissula merupakan Perguruan Tinggi Swasta Islam (PTSI) yang bekerja keras mendapatkan kepercayaan masyarakat melalui peningkatan mutu akademik dosen dan mahasiswa. Untuk permasalahan penelitian yang dikaji dalam penelitian ini, yaitu mengenai dimensi konstruksi makna Marketing PR di Unisba dan Unissula. Penelitian ini merupakan penelitian kualitatif dengan pendekatan studi kasus. Teori yang digunakan untuk mengkaji dan menganalisis hasil penelitian adalah teori konstruksi sosial (Berger dan Luckman). Hasil penelitian menyatakan bahwa konstruksi makna Marketing PR, yaitu: 1) seni mempengaruhi stakeholders dalam kerangka human relations, 2) niat ibadah karena Allah SWT (Lillahi Ta'ala) yang berlandaskan kesabaran, kejujuran, dan keteladanan, 3) bertujuan meningkatkan jumlah calon mahasiswa dan membangun citra positif, serta 4) Marketing PR mengedepankan nilai Islam yang mengandung nilai dakwah dan syi'ar Islam.
\end{abstract}

Kata Kunci: Marketing Public Relations, Konstruksi Sosial, Syariat Islam.

Copyright () 2018 Universitas Semarang. All rights reserved.

\section{Introduction}

The phenomenon of the establishment of public and private higher education at this time, causes a higher education to face competition in providing qualified education. Private Universities realize that to be able to compete with other universities they should have competitive advantage and have uniqueness that become the corporate

Article History: Received March 17, 2018; Revised July 22, 2018; Accepted July 26, 2018; Published July 31, 2018 
identity of the private universities in the minds of stakeholders, so the private universities can be recognized by the public.

Universitas Islam Bandung (Unisba) and Universitas Islam Sultan Agung Semarang (Unissula) are universities that have their own peculiarities, namely the Private Universities based on Islamic values. This is the uniqueness and identity of the institutions in the minds of stakeholders, basically the private universities as a brand is built from the identity shown. The identity as Islamic Private Higher Education is manifested in the campus symbol, as well as the academic and non-academic activities. This identity raises the perceptions or images of the institution in the minds of stakeholders.

Public relations (PR) activities are promotional tools for universities, where universities must build good relationships with various public by gaining favorable publicity, establishing good corporate image and dealing with or eliminating unfavorable rumors, stories, or events. PR Marketing is one concept that can be used in promotional activities in higher education, where Marketing PR is a synergy between marketing strategy and public relations activities.

PR of Unisba and Unissula conduct PR Marketing activities in an effort to introduce the institutions to stakeholders, so that the institutions are expected to be better known by the public. PR Marketing activities carried out cannot be separated from the Islamic values. This is the uniqueness of this research, the implementation of PR Marketing should contain the values of da'wah and syi'ar, ranging from marketing media, how to communicate, as well as the attitude built must be based on Islamic Shari'a. Mubarok and Marhaeni (Mubarok \& Marhaeni K., 2016) in their research entitled 'The Construction of the Principles of Public Relations Performance in Islamic Shari'a View' explains that: in the principle of Islam, it is emphasized for its people to behave according to the principles of truth (QS. At-Taubah: 119) and Islam also emphasizes that his people always hold the principle of honesty (QS. Muhammad: 21). This means that PR Marketing activities run by public relations of Unisba and Unissula must prioritize the values of truth and honesty.

Based on these problems, the researchers examine and analyze the dimensions of the meaning construction of PR Marketing in Unisba and Unissula by using Berger and Luckman Social Construction Theory to analyze the field findings. Therefore, the researchers feel the need of studying and discussing them in depth through research 'The Meaning Construction of PR Marketing for Islamic Private Higher Education Public Relations: Case Study in Unisba and Unissula'.

\section{Methodology}

This study uses case study approach with interpretive (constructivism) approach, where the researchers want to know and interpret PR Marketing from the perspective of Unisba and Unissula PR. Stake in Creswell (Creswell, 2012), case study is a research strategy in which the researchers investigate a program, event, activity, process, or group of individuals carefully. Cases are limited by time and activity, and the researchers collect information completely by using various data collection procedures at predetermined time. While Scharmm (Yin, 2002) describes the case study, which is an approach to study, to explain, or to interpret a case in a natural context without any outsider intervention.

In this research, the researchers want to know and understand the meaning of PR Marketing and then interpret it, explain the process of the meaning formation and 
explain the matter and how the meanings contained in Unisba and Unissula public relations' language and action. According to Jalbert (Mulyana, 2002), social reality is considered social interaction that is communicative. In this study, PR Marketing is social reality as social interaction conducted by public relations with internal and external public that is communicative. Researchers make direct observation in detail on the subject of research in a natural daily setting, in order to be able to understand and interpret how Private Universities PR create and manage PR Marketing.

The research process was carried out through observation on PR Marketing activities in Islamic Private Higher Education (starting in 2014), asking questions to informants, collecting various specific data, analyzing data inductively from the specific to the general, and interpreting the meaning of the data about PR Marketing in Unisba and Unissula. Informants in this study consist of: 1) Unisba and Unissula PR, 2) Vice Rector for Academic, and Vice Rector for Administration and Finance of Unisba, 3) Vice Rector for Student Affairs of Unissula. Based on the existing phenomenon in the field, this research uses case study approach with multi case design about Public Relations Marketing. This research is included in multi case design because the unit of analysis is more than one, namely Unisba and Unissula PR Marketing activities.

\section{Result and Discussion}

The Dimensions of Meaning Construction of Unisba and Unissula Public Relations Marketing

Based on the findings of research in the field regarding the meaning construction of PR Marketing for Unisba and Unissula PR, the researchers categorize the meaning construction of PR Marketing into the dimensions of meaning, intention/purpose, motive, and the concept of Islamic PR Marketing.

Meaning is a further effort of interpretation, and has parallel with extrapolation and the meaning of more demands the integrative ability of human, his senses, his mind and his thought (Basrowi \& Sukidin, 2002). Meaning comes from one's social interaction with each other and that meaning is treated or changed through the interpretive process that people use in interpreting a social phenomenon. In the context of this research, the meaning of PR Marketing is interpreted by Unisba PR as the art of influencing prospective students and stakeholders by prioritizing the aspects of education in the framework of human relations, while UPT PR and Marketing of Unissula more emphasize the aspect of trust and perform the da'wah function in PR Marketing activities.

Intention in communicating within which the purpose is covered, is the first starting point to determine whether a communication action is considered good or not (Venus \& Nantia, 2016). In the context of good communication, it must be initiated by good intention and not the factor of the person in question but the essence of communication intention itself. That the act of communication should be based on good intention and objective. Good intention or goal should be the point of departure of a good communication action. This is in line with Frank Jefkins' statement in the Public Relations book: "Public Relations is a system of communication to create a goodwill, it means Public Relations is a communication system to create good intentions."

Antar Venus and Nantia Rena Dewi (Venus \& Nantia, 2016) explain that if the aspect of communication purpose or intention is related to what for a communication action is done, then the aspect of agreement is more related to the fact that communication is an action involving other parties. In this context, the dimension of 
agreement has two important aspects to consider, namely aspects of personal agreement and social agreement. Personal agreement is defined as a situation where the intention we share in common by the person who becomes the communication partner. Social agreement is communication actions should take into account aspects of social values or norms applied to the community groups where the communication take place. Aspect of delivery is the most crucial aspect, this aspect relates to how the action of communication is done. While the reception of messages is the achievement of communication, in the perspective of good communication the achievement is not unilateral but it involves both parties.

In the context of this research, Unisba PR Marketing activities must be based on lillahita'ala intention based on patience, honesty and exemplary aspects. The motives of the implementation of PR Marketing activities in Unisba is to increase the number of prospective students and to build positive image of Unisba, image as an Islamic college that puts forward ruhuddin. While Unissula's PR Marketing activities intention is based on exemplary and honesty. The motives of the implementation of PR Marketing activities are to build khaira ummah generation and to build image of Unissula as an educational institution that promotes the formation of noble characters. To achieve this goal, Public Relations involves various parties, including promotional teams coming from faculty representatives, either lecturers, staffs and students, where PR marketing activities are conducted directly or in accordance with prevailing social values and social norms. As an example; when the promotion team did a presentation at the pesantren, for the ikhwan class then the one explaining the material is $i k h w a n$, while for the class of akhwat then the one explaining the material is akhwat.

The acceptance or achievement of communication in PR Marketing activity is the promotion team educates the students about the college and students get information about university so it opens the students' insight in choosing the major or study program according to their interest. This is what meant by the communication achievement is not unilateral but involves both parties. So good communication achieves the same intention and meaning among communication actors. In this context the measurement of the goodness of PR Marketing activities is the benefit for the institutions and stakeholders.

Social Construction in Public Relations Marketing

Based on the field findings through in-depth interviews with the resource persons, observations of researchers in the field, and various literature study related to the meaning construction of PR Marketing, the researchers will analyze and discuss it based on theories and concepts relevant to PR Marketing.

In the context of this study, PR Marketing is reality, PR Marketing activity is a reality that exists within society and is constructed by individuals involved in PR Marketing activities. According to Sukidin (Basrowi \& Sukidin, 2002) reality is the creation result of creative people through social construction of the social world around them. The social construction of reality theory assumes that social reality (society) is constructed. PR Marketing activities are the result of institutional construction, and once deployed it will be constructed by the public. PR needs to understand social construction by observing the symbols and meanings contained in messages that are constructed and distributed by the institution. Unisba PR, and Unissula Head of Public Relations and Marketing interpret PR Marketing as the synergy between Marketing activities and PR strategy, where this activity should be based on Islamic values depicted in messages and media visualization campaign. Social Construction Theory (Berger \& Luckman), various communication media, such as press release, newsletter, 
company profile, bulletin, or institutional website should be well designed, thereby affecting positive public construction on the institution. It means that what is constructed must correlate with what is done.

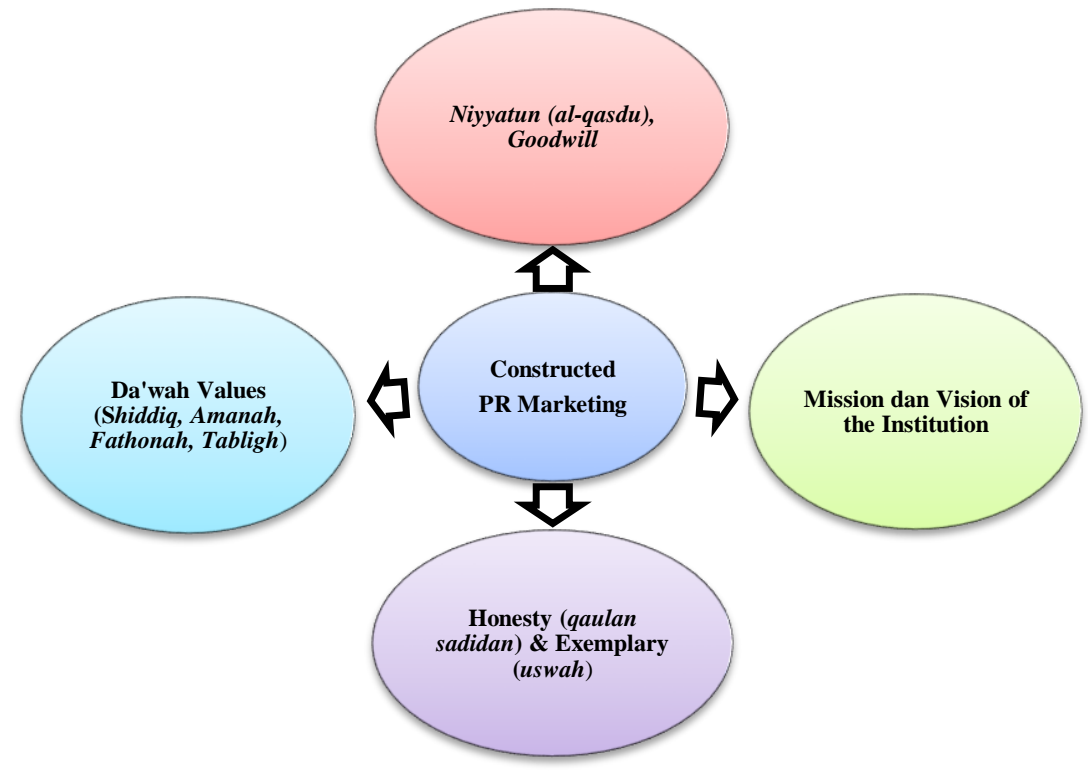

Figure 1. Social Construction Model in PR Marketing

Source: The Results of the Researchers' Study

Society in the perspective of Bungin (Bungin, 2011), is an objective reality, in which there is an institutionalization process built based on habituation. Adopting the views of Berger and Luckman, PR Marketing is an objective reality in which there is an institutionalization process, where PR Marketing is constructed based on the mission and vision of institution built based on habituation. Institutionalization encompasses the symbolic universe, namely the meaning objectivation process of institutional identity that serves to integrate the meanings already given to the institutionalization process.

The meaning construction of college PR Marketing is built by PR and management based on the mission and vision of the institution. The meaning construction process of PR Marketing is formed through the stages of giving the meaning and applying the mission and vision of the institution in PR Marketing by paying attention to the audience or target of the activities of college PR Marketing. PR Marketing is then packaged in the form of creativity, art, and activities in an effort to create positive image and reputation of the college. The reality of college PR Marketing is constructed by public relations and management that become part of the social reconstruction of its people. Therefore, according to Burhan Bungin (Bungin, 2011), "The dependence of those who live in social reality is the people who always have this awareness of reality, as they realize themselves as part of reality itself."

Unisba and Unissula PR Marketing are constructed as an activity that begins with 'good intentions' because of Allah SWT and must contain da'wah values by giving priority to honesty and exemplary. The original word of intention comes from Niyyatu means the will or al-qasdu that is the convinced heart of doing something and the strong will to do it without any doubt. Public Relations is a variety of implementation of communication activities based on good intentions. This good intention is implemented in the form of 'da'wah' through symbols, among other is language that is packed in an effort to form mutual understanding between universities and stakeholders. 
The effort to establish mutual understanding is one of the goals of PR activities. The British Institute of Public Relations (Yulianita, 2016) states: "Public Relations practice is adeliberate, planned and sustained effort to establish and maintain mutual understanding between an organization and public." In the context of this study, PR Marketing activities are conducted in an effort to create and build mutual understanding between universities and stakeholders through building good relationship with teachers, schools, and high school students. This is based on the function of Public Relations (Kriyantono, 2014), namely: creating understanding and cooperation between the organization and the public to achieve mutual desire.

Meanwhile, language is the most important symbol in social construction, language bridging different regions of everyday life and integrating it into a meaningful whole (Bungin, 2011). Language is the most important symbol in constructing reality. Language is used to share meaning and experience and language is used for message dissemination in the process of objectification and internalization of knowledge. Message dissemination is PR Marketing activity directed to the target audience for obtaining information that arises awareness, accepting and eventually utilizing the information. In PR Marketing activities, the language is expressed through the activities directly (face to face) or mediated through the media used in PR Marketing activities. Language is expressed courteously and adapted to the values and norms based on the Islamic Shari'a.

Knowledge is derived from the social process in which knowledge is the result of human construction about their world through interaction with others (Kriyantono, 2014). The knowledge on Unisba and Unissula as Islamic university becomes a truth or knowledge in the society. This knowledge is often the truth that is believed (taken for granted) in society over a period of time. This truth must be directly proportional to Ruhul Islam (ruhuddin) enhancement and development policy in Unisba and to form 'insan khaira umah' in Unissula. All of these are implemented in educational and teaching programs, research, community service, and activities that are followed by all Unisba and Unissula academicians. It is not easy for Unisba and Unissula to force their construction as the taken for granted knowledge for society, as private university based on Islamic values. The development of communication technology enables widespread public discourse, thus affecting public attitudes towards institutional construction.

One uniqueness of Unisba and Unissula PR Marketing activities as an Islamic college is to put forward honesty and exemplary. Currently, truth and honesty are the foundation of life, including in the activities of Public Relations. One focus on Declaration of Principles of Public Relations: Tell the Truth (Kriyantono, 2014), public relations profession must be honest and open in conveying the truth so as to maintain reputation. The importance of honesty because public relations is the representation of organization and the public through boundary-spanning activities, which also struggling for public aspirations. Based on the code of conduct of Perhumas profession which is based on "Code of Conduct of Public Relations" and inspired by the Charter of the United Nations as the foundation of the international order of life, and based on the Asean Declaration as the unifying of the peoples of Southeast Asia, described in Article 2 on the behavior towards clients, paragraph 1: be honest in dealing with clients, leaders, and institutions. By communicating open and correct information, the organization can meet the information needs and gain the trust from the public.

The principle of honesty to tell the truth according to fact, accuracy, objective, and not manipulative that deceive the public is the principle of Public Relations 
communication. Public Relations convey the true words, both from the content of the message and the selection of words. Neni Yulianita in the book 'Indonesia Bicara Baik' (Yulianita, 2016) and Rachmat Kriyantono (Kriyantono, 2014), explain about the principles of Public Relations communication in the perspective of Islam, one of them is Qaulan Sadidan which means the true words. The basic principle is QS. An-Nisa: 9: "And be afraid of Allah those who, if they have left behind their weak offspring behind them, and worry about their welfare. Therefore, they should be cautious to Allah and speak with the correct words" (Al-Qur'an Al-Mu'asir). In the context of this study, PR Marketing must be constructed using words that do not hide the truth or do not make the truth vague. Trimanah and Wulandari (Trimanah \& Wulandari, 2018) explain that; "PR always tries to do the best and puts forward honesty in every words, actions, and deeds. Although the facts conveyed are inadequate or unfavorable in forming opinion or image, then without neglecting the matter of the truth delivery, PR should give certain argument that confirms the deficiency. In short, the PR should still convey the truth but with additional arguments that as far as possible can be understood by the public".

The meaning of exemplary in PR Marketing means PR Marketing activity is also determined by the behavior of individuals within the organization. Each academic community in Unisba and Unissula contributes to speak, act, and behave in accordance with Islamic values so as to provide exemplary for the community. In addition, academic community is expected to provide information that can create positive image in the public eye. Public Relations is living presentation for the organization, PR serves to maintain good morality and manners in the organization (Kriyantono, 2014). In the context of PR Marketing, the academic community should be the role models, ranging from dressing, behavior to integrity shown everyday. Mubarok and Marhaeni (Mubarok \& Marhaeni K., 2016) explain that: "Prophet Muhammad Shallalahu Alaihi wa Sallam gave role model to his people so that in the society practice human always behave, act gentle to fellow Muslim or non-Muslim. Rasulullah preached in syiri way or surreptitious. The persons who first got the guidance of da'wah are the closest persons, i.e. wife, relatives, friends, and brothers". This means that PR Marketing activities must be first based on the exemplary aspects of the institution's internal public, in an effort to build positive image and reputation of the institution.

Islamic PR Marketing is concept of PR Marketing that prioritizes Islamic values in it, not just as implementing PR Marketing but must also have the value of da'wah and value of syi'ar in it so that start from marketing tools used, then how to communicate done, as well as the attitude built always seeks on Islamic values, among others are Shidiq, Amanah, Fathonah and Tabligh. This is one of Unisba and Unissula similarities in constructing the meaning of PR Marketing, namely organizational culture.

Organizational culture (Littlejohn \& Foss, 2009) is something that is generated through daily interactions within the organization - not just the job task, but all kinds of communication. When understanding Littlejohn and Foss's views on organizational culture, PR Marketing is part of the organizational culture, because PR Marketing is communication activity. Organizational culture is strongly influenced by sociocultural traditions in communication (Littlejohn \& Foss, 2009). In this tradition, organizations provide opportunities for cultural interpretation, organizations create a shared reality that differentiates an organization from other organizations. Unisba and Unissula PR Marketing will be different from other college PR Marketing.

Based on the above discussion, it is necessary to have PR Marketing strategy that focuses on the public interest and the interests of the institution. Unisba and Unissula 
PR realize the role of mass media and virtual media in creating social reality, so they must establish good relations with the media through understanding the media and meet the media needs. Understanding the media means PR understand the characteristics and work process of media, and media needs means the availability of information that is open, clear, and honest. This is where the importance of media relations made by Unisba and Unissula Public Relations, there is mutualism symbiotic relationship between the two. By establishing good relations with the mediamutualism symbiotic, it can maintain positive image of the institution in the minds of the people.

\section{Conclusion}

Based on the field findings, there are four dimensions of the meaning construction of Unisba and Unissula PR Marketing, namely: 1) The meaning of PR Marketing for PR is the art of influencing stakeholders in the human relations framework and carrying out the da'wah (syi'ar) function. 2) Intention to carry out PR Marketing activities for PR is the intention of worship because of Allah SWT (Lillahi Ta'ala) based on patience, honesty, and exemplary. 3) PR Marketing motive for PR is to increase the number of prospective students and to build positive image. Promoting ruhuddin and the formation of noble character. 4) The concept of Islamic PR Marketing is PR Marketing activities that prioritize the Islamic values that contains the value of Islamic da'wah and syi'ar.

\section{Acknowledgement}

Acknowledgments conveyed to the Directorate of Research and Community Service, Directorate General of Research and Development Strengthening, Ministry of Research, Technology and Higher Education of the Republic of Indonesia (Kemenristekdikti RI), through 2017 Doctoral Dissertation grant. This research article is part of dissertation research entitled: "Marketing Public Relations di Perguruan Tinggi Islam Swasta: Studi Kasus di Humas Universitas Islam Bandung dan Universitas Islam Sultan Agung Semarang (Public Relations Marketing in Islamic Private Universities: Case Study in Universitas Islam Bandung and Universitas Islam Sultan Agung Semarang)".

\section{References}

Al-Qur'an \& Terjemahan. (2007). Mushaf Sahmalnour.

Basrowi, \& Sukidin. (2002). Metode Penelitian Kualitatif Perspektif Mikro. Surabaya: Insan Cendekia.

Bungin, M. B. (2011). Konstruksi Sosial Media Massa: Kekuatan Pengaruh Media Massa, Iklan Televisi dan Keputusan Konsumen serta Kritik terhadap Peter L. Berger \& Thomas Luckmann. Jakarta: Kencana Prenada Media.

Creswell, J. W. (2012). Qualitative Inquiry Research Design: Choosing among Five Approaches. California: SAGE Publications.

Kriyantono, R. (2014). Teori Public Relations Perspektif Barat dan Lokal: Aplikasi Penelitian dan Praktik. Komunikasi UB.

Littlejohn, S. W., \& Foss, K. A. (2009). Teori Komunikasi (Edisi 9). Jakarta: Salemba Humanika.

Mubarok, \& Marhaeni K., D. (2016). Konstruksi Prinsip Kinerja Public Relations dalam Pandangan Syariat Islam. Jurnal The Messenger, 8(2), 20-34. Retrieved from http://journals.usm.ac.id/index.php/the-messenger/article/view/338/229

Mulyana, D. (2002). Metodologi Penelitian Kualitatif Paradigma baru Ilmu 
Komunikasi dan Ilmu Sosial lainnya. Bandung: Remaja Rosdakarya.

Trimanah, \& Wulandari, D. (2018). The Perception of Perhumas Central Java Members on Principles of PR Performance in Islam. Jurnal The Messenger, 10(1), 124-134. Retrieved from http://journals.usm.ac.id/index.php/themessenger/article/view/594/521

Venus, A., \& Nantia, R. D. (2016). Komunikasi yang Baik. Dalam Pandangan Barat, Timur, dan Indonesia. In Indonesia Bicara Baik: Bunga Rampai Komunikasi dan Humas. Bandung: Pelangi Publika.

Yin, R. K. (2002). Studi Kasus: Desain dan Metode. Jakarta: RajaGrafindo Persada.

Yulianita, N. (2016). Komunikasi yang Baik. Dalam Pandangan Barat, Timur, dan Indonesia. In Indonesia Bicara Baik: Bunga Rampai Komunikasi dan Humas. Bandung: Pelangi Mitra Sukses. 